\title{
Internal Information Environment and Labor Investment Efficiency
}

\author{
Xin Luo $^{1} \&$ Fan Zhang ${ }^{2}$ \\ ${ }^{1}$ College of Business Administration, Marquette University, Milwaukee, WI, USA \\ ${ }^{2}$ W. P. Carey School of Business, Arizona State University, Tempe, AZ, USA \\ Correspondence: Xin Luo, College of Business Administration, Marquette University, Milwaukee, WI 53233, USA.
}

Received: October 20, 2020

Accepted: November 16, 2020

Online Published: November 23, 2020

doi:10.5430/afr.v9n4p70

URL: https://doi.org/10.5430/afr.v9n4p70

\begin{abstract}
This study investigates the relation between internal information environment and labor investment efficiency. We argue that better internal information quality allows managers to obtain more timely and accurate information from subordinates and therefore make better decisions in labor investments. Our results suggest that the labor investments of firms with high quality internal information have less deviation from the optimal level. This association holds for both companies in industries with high and low union coverage.
\end{abstract}

Keywords: labor investment efficiency, internal information, decision-making, labor union

\section{Introduction}

According to neoclassical economic theories (e.g. Cobb \& Douglas, 1928), both labor and capital are input of the production function and the labor investment efficiency has a direct impact on firms' economic outputs. Consistent with this notion, management literature documents that human resource is closely associated with firm performance and firm value (Becker \& Gerhart, 1996; Veltri \& Silvestri, 2011). Salary and employee benefits account for a significant portion of corporate expenditure and have seen steady increase overtime. According to US Bureau of Labor Statistics, the cost of compensation and employee health benefits for private industry workers increased by $2.7 \%$ and $1.9 \%$ over 2019 calendar year, respectively (Note 1 ).

Despite the direct and important impact of labor investment on economic outputs and corporate expenditure, only a few accounting and finance studies investigate the determinants and outcomes of labor investment efficiency (e.g., Ding, Ni, \& Xu, 2020; Jung, Lee, \& Weber, 2014; Ghaly, Dang, \& Stathopoulos, 2020; Ben-Nasr \& Alshwer, 2016; Jung, Kang, Lee, \& Zhou, 2020). Our knowledge on labor investment efficiency is still limited. Jung, Kim, Lee, and Yoo (2016) find that layoff decisions of U.S. corporations on average are not efficient, even though the main purpose of layoff should be adjusting the excessive labor cost to the optimal level. Improvement of labor investment efficiency can potentially enhance firms' productivity and alleviate firms' stress from the increasing employment costs, thus it plays an important role in corporate performance.

This study aims to investigate factors that are related to efficient corporate labor investment. Specifically, we explore an information channel and focus on the internal information environment. Decision theory suggests that the quality of information that managers rely on has an impact on the outcome of their decision making. We follow Gallermore and Labro (2015) and define the internal information quality as "the accessibility, usefulness, accuracy, and quantity of the information collected, generated and consumed within an organization". Information collected and generated from external resources and within a firm plays an important role in the managers' decision making, including the important decisions such as labor investment.

It is crucial to understand the causes of labor investment inefficiency in order to improve the firms' economic outcomes. Labor investment inefficiency may be driven by managers' self-serving incentives, legal environment, and the information environment. Over-investment in labor may be caused by managers' over optimistic prospect for the firm's future operation or agency problems including managers' empire building incentives. Under-investment in labor may be caused by managers' over pessimistic prospect for the firm's future performance and managers' incentives to meet short-term goals (Jung et al. 2014). Literature further documents the impact of information on labor investment decisions. A few recent studies document that labor investment efficiency may be influenced by the information asymmetry between managers and capital providers (Jung et al. 2014), the market pressure and 
monitoring (Ding et al., 2020), the monitoring from institutional investors and other financial statement users (Ghaly et al., 2020; Zhang, Ntim, Zhang, \& Elmagrhi, 2020), and the laborism (Jung et al., 2020), etc.

Our research uncovers a different force that drives managers labor investment decisions, that is managers' access to high quality internal information. Managers demand high quality information to develop their prospect for firms' future performance and make decisions accordingly. As a result, important decisions including labor investments can be affected heavily by the information environment. For instance, Ben-Nasr and Alshwer (2016) document a positive association between the informativeness of stock price and labor investment efficiency. While stock price is an external information source, we anticipate that, consistent with this information mechanism, internal information quality is also related to labor investment efficiency.

Following Pinnuck and Lillis (2007) and Jung et al. (2014), we construct the measure of labor investment inefficiency using the abnormal hiring. We regress net hiring on several economic determinants and then obtain the expected hiring. Then we take the difference of actual hiring and expected hiring as the abnormal part of labor investment. To capture the internal information quality, we use two proxies: earnings announcement speed and management forecast accuracy, following Gallemore and Labro (2015). We then investigate the relations between the magnitude of abnormal labor investment and proxies for internal information quality. Regression results show that labor investment tend to be more efficient for firms with faster earnings announcement and more accurate management forecast. This suggests the labor investment decisions benefit more from internal information that is collected, aggregated, and processed in a more timely and accurate manner.

We further consider the heterogeneous impact of internal information quality on labor investment efficiency across different association of labor union. In unionized industries, management needs to reach an agreement on hiring and firing decisions with labor union. In order to protect current employees' interest, labor unions are more likely to prevent firms from hiring and firing and at the same time demand higher salary and employee benefit. As a result, firms with strong labor union present stickiness in reaching optimal level of labor investment. We document that such firms demand better decisions in labor investment and exhibit a higher improvement in efficiency with high quality of internal information.

Our findings contribute to the growing discussion on labor investment efficiency and a broader line of research that investigates corporate investment efficiency. Although capital investment efficiency has been extensively examined in accounting and finance literature (e.g., Biddle, Hilary, \& Verdi, 2009; Beatty, Liao, \& Yu, 2013), our knowledge on labor investment efficiency is still limited. This issue is more critical during the pandemic time when more organizations see massive layoff and slowing-down hiring. Firms with efficient hiring and firing decisions are more likely to survive or thrive the economy downturn. Our findings highlight the importance of internal information quality in facilitating labor investment efficiency.

Our research also sheds light on the importance of internal information environment in managers' decision making. Better internal information environment facilitates the identification of inefficiency in operation and investment and help managers develop more accurate prospects for future performance. Prior literature documents the importance of internal information quality in tax avoidance (Gallemore \& Labro, 2015), communication with external stakeholders (Chen, Martin, Wang, Roychowdhury, \& Billet, 2018), and investment sensitivity to market value and cash flow (Heitzman \& Huang, 2018). Our study extends prior research by investigating the impact of internal information environment on managers' labor investment decisions and demonstrates that this impact is substantial.

The rest of the paper is organized as follows. Section 2 discusses prior literature and develops the hypothesis; Section 3 introduces research design, Section 4 covers sample selection and descriptive statistics, Section 5 presents the empirical results and additional analyses, and Section 6 concludes this research.

\section{Literature Review and Hypothesis Development}

In this section, we first review literature on labor investment efficiency. We then explain how internal information environment can impact the quality managers' labor investment decisions so as to arrive at our hypothesis.

\subsection{Review of Labor Investment Literature}

A few accounting papers study the determinants and consequences of managers' labor investment decisions. Layoffs decisions of US firms on average do not improve labor investment efficiency but further deviate the labor investment level from the optimal level (Jung et al. 2016). Pinnuck and Lillis (2007) and Dechow, Ge, Larson, and Sloan (2011) find that firms with poor earnings performance are likely to have an abnormal reduction in labor investment to improve short-term performance. However, the abnormal reduction in labor investment leads to negative stock market reaction (Jung et al., 2016) and is likely to harm earnings performance in the long-run (Jung et al., 2014). 
Some papers consider the role of agency conflicts in labor investment decisions. Jung et al. (2014) find that higher financial reporting quality reduces the information asymmetry between managers and external capital suppliers and further leads to more efficient investment in labor. They find that both over- and under-investment in labor are mitigated by higher financial reporting quality and this mitigation effect is more pronounced for firms in industries with high levels of unionization. Zhang et al. (2020) document that accounting comparability serves as a monitoring tool that mitigates the agency conflicts and, as a result, improves labor investment efficiency. Ghaly et al. (2020) document that long-term institutional investors engage in effective monitoring and further improve the labor investment efficiency.

Labor and capital investment decisions contain managers' private information about firms' profitability (Li, 2011). High quality information assists managers in developing their prospect of firms' future performance and further improve labor investment efficiency. Ben-Nasr and Alshwer (2016) argue that mangers aggregate their private information by learning from stock prices and their increased private information improves decision efficiency. They find that stock price informativeness improves labor investment efficiency by mitigating the effects of labor union and financial constraints on labor investment.

A few studies also examine other forces that drive the labor investment efficiency. For instance, Ding et al. (2020) shows that short selling is associated with lower labor investment efficiency. Khedmati, Sualihu and Yawson (2019) studies that how CEOs' ties with independent board members can affect the labor investment efficiency.

\subsection{Internal Information Environment and Labor Investment Efficiency—HypothesisDevelopment}

When the usage of property, plants, and equipment reach the capacity, having more employees does not improve production efficiency. Managers may need to consider layoff or increasing capital investment to match labor capacity with production capacity. They can replace less efficient workers with better ones, provide employees additional training, offer employees incentives to work harder. Improvement in employees' performance directly increases the operating efficiency and labor investment efficiency.

Prior research shows that better internal information quality is associated with managers decision making in tax avoidance (Gallemore \& Labro, 2015), tax-motivated income shifting (McGuire, Rane, \& Weaver 2018), capital allocation (Weber \& Zheng, 2017), innovation efficiency (Huang, Lao, \& McPhee, 2020), and cash holding (Xiong, Zheng, An, \& Xu, 2020). High quality internal information allows managers to effectively and efficiently consolidate information provided by subordinates and facilitates managers' decision-making in labor investments from several aspects. First, higher quality of internal information assists managers in identifying deficiency and surplus in production. Second, managers heavily rely on internal information when they evaluate employees' performance. Third, internal information quality helps managers develop a better estimation of the accessibility of internal and external capital. Last but not least, internal information helps managers develop their prospect for firms' future performance and operating environment and further adjust various corporate strategies, including labor investment. Thus, we expect that better internal information from internal personnel helps improve labor investment efficiency.

Hypothesis: Ceteris paribus, internal information quality is positively associated with labor investment efficiency.

\section{Research Design}

\subsection{Measure of Labor Investment Efficiency}

We use firms' net hiring (NET_HIRE), measured by changes in their number of employees, to proxy for investment in labor (e.g., Pinnuck \& Lillis, 2007; Li, 2011; Jung at al., 2014). Based on the model developed by Pinnuck and Lillis (2007), we first regress net hiring on variables that capture the economic fundamentals that determine firms' hiring or firing activities. These variables include sales growth, changes in profitability, profitability, stock return, firm size, liquidity, and firm leverage. We also control for industry fixed effect using the 48-industry classification developed by Fama and French (1997). We then obtain the residual as the abnormal net hiring, which is the difference between actual net hiring and expected net hiring. We next take the absolute value of abnormal hiring (ABS_AB_NET_HIRING) and use it as a proxy for labor investment efficiency. Specifically, higher magnitude of abnormal hiring indicates lower labor investment efficiency. Equation (1) presents the main regression model that we use to estimate the abnormal net hiring:

$$
\begin{aligned}
\text { NET_HIRE }_{i t}= & \beta_{0}+\beta_{1} \text { SALES_GROWTH }_{i t}+\beta_{2} \text { SALES_GROWTH }_{\mathrm{it}-1}+\beta_{3} \text { Delta_ROA }_{\mathrm{it}}+\beta_{4} \text { Delta_ROA }_{\mathrm{it}-1}+ \\
& \beta_{5} \text { ROA }_{\mathrm{it}}+\beta_{6} \text { RETURN }_{\mathrm{it}}+\beta_{7} \text { SIZE_R }_{\mathrm{it}-1}+\beta_{8} \text { QUICK }_{\mathrm{it}-1}+\beta_{9} \text { Delta_QUICK }_{\mathrm{it}-1}+ \\
& \beta_{10} \text { Delta_QUICK }_{\mathrm{it}}+\beta_{11} \text { LEV }_{\mathrm{it}-1}+\beta_{12} \text { LOSSBIN }_{\mathrm{it}-1}+\beta_{13} \text { LOSSBIN }_{\mathrm{it}-1}+\beta_{14} \text { LOSSBIN }_{\mathrm{it}-1}+ \\
& \beta_{15} \text { LOSSBIN }_{\mathrm{it}-1}+\beta_{16} \text { LOSSBIN }_{\mathrm{it}-1}+\sum \text { INDUSTRY }_{\mathrm{it}}+\varepsilon_{\mathrm{it}}
\end{aligned}
$$


where NET_HIRE represents the percentage change in the number of employee; SALE_GROWTH is the percentage change in sales; ROA is the net income scaled by total assets at the beginning of the fiscal year; Delta_ROA is the change in ROA; RETURN is buy-and-hold return over the fiscal year; SIZE_R is the percentile ranking of the market value of equity; QUICK is the quick ratio and is calculated as the sum of cash, short term investments, accounts receivables divided by current liabilities; Delta_QUICK is the percentage change in quick ratio; LEV represents the total debt to total assets ratio; LOSSBIN measures small losses; LOSSBIN1 is equal to 1 if ROA ranges from -0.005 to 0 ; LOSSBIN2 is equal to 1 if ROA is between -0.005 and -0.010 ; LOSSBIN3, LOSSBIN4, and LOSSBIN5 are defined similarly.

\subsection{Measure of Internal Information Quality}

We use two measures to proxy internal information quality, following prior research (e.g., Cheng, Cho, \& Yang, 2018; Gallemore \& Labro, 2015; Heitzman \& Huang, 2019). We use the outcome of managers' usage of internal generated information to measure internal information quality (IIQ). The first proxy is the earnings announcement speed (EA_SPEED), which equals to the number of days between the end of fiscal year and earnings announcement date scaled by 365 and times negative one. Faster earnings announcement speed suggests a more sophisticated accounting system and faster information acquisition and integration from different part of the organizations (Jennings, Seo, \& Tanlu, 2019).

The second proxy is the management forecast accuracy (FORECAST_ACCURACY). It is measured as the magnitude of the difference between management last available forecast for earnings per share and actual earnings per share scaled by the stock price at year end and multiplied by negative one. Internal information generated from internal reports and information system is important input of management forecast (Cassar \& Gibson, 2008; Dorantes, Li, Peters, \& Richardson, 2013; Gong, Li, \& Xie, 2009). More accurate management forecast suggests better internal information environment.

\subsection{Empirical Model}

To test our hypothesis, we regress the magnitude of abnormal net hiring (ABS_AB_NET_HIRING) on lagged internal information quality (IIQ), and control variables associated with labor investment decisions. Managers can adjust the labor investment plans based on contemporaneous firm performance and characteristics and labor investment in return can contribute to changes in firm performance and characteristics. In order to avoid potential reverse causality issue, our variables of interest and control variables are all in lagged form.

Following Jung et al. (2014), we control for lagged growth opportunities (MTB), lagged firm size (SIZE), lagged liquidity (QUICK), lagged leverage (LEV), lagged dividend payout (DIVDUM), lagged operating cash flow and sales volatilities (STD_CFO and STD_SALES), lagged tangibility (TANGIBLE), lagged incidence of losses (LOSS), lagged hiring volatility (STD_NET_HIRE), lagged labor intensity (LABOR_INTENSITY), abnormal non-labor investment (ABS_AB_INVEST_OTHER). Our primary regression is based on the following equation:

$$
\begin{aligned}
\text { ABS_AB_NET_HIRING } & \\
& =\beta_{0}+\beta_{1} I I I Q_{i t-1}+\beta_{2} \text { MTB }_{i t-1}+\beta_{3} \text { SIZE }_{i t-1}+\beta_{4} \text { QUICK }_{i t-1}+\beta_{5} \text { LEV }_{i t-1}+\beta_{6} \text { DIVDUM }_{i t-1} \\
& +\beta_{7} \text { STD_CFO }_{i t-1}+\beta_{8} \text { STD_SALES }_{i t-1}+\beta_{9} \text { TANGIBLE }_{i t-1}+\beta_{10} \text { LOSS }_{i t-1} \\
& +\beta_{11} \text { STD_NET_HIRE }_{\text {it }-1}+\beta_{12} \text { LABOR_INTENSITY }_{\text {it }-1}+\beta_{13} \text { ABS_AB_INVEST_OTHER }_{\text {it-1 }} \\
& +\sum \text { INDUSTRY }_{\text {it }}+\sum \text { YEAR }_{i t}+\varepsilon_{i t}
\end{aligned}
$$

where MTB is the marker to book ratio of common equity; SIZE is the logarithm of market value of equity; DIVDUM equals one if the firm pay dividend, and zero otherwise; STD_CFO is the standard deviation of operating cash flow over five years; STD_SALES is the standard deviation of sales over five years; TANGIBLE is the ratio of PPE to total assets; LOSS is an indicator variable equal to one if firm reports a loss; STD_NET_HIRE is the standard deviation of percentage change in the number of employee over five years; LABOR_INTENSITY is the ratio of employees to total assets at the beginning of fiscal year; ABS_AB_INVEST_OTHER is the magnitude of abnormal non-labor investment following Biddle at al. (2009); all other variables are as previously defined. (Note 2)

\section{Sample Selection and Descriptive Statistics}

\subsection{Sample Selection}

To construct our sample, we collected financial data from Computstat, earnings announcement data and management 
forecast data from IBES, and union coverage data from Union Membership and Coverage Database (Note 3). To avoid the impact of Sarbanes-Oxley Act (SOX) of 2002 on managers' decision making, our sample period starts in fiscal year 2004 and runs from 2004 to 2018. Year fixed effects also help mitigate the subsequent impact of SOX in the following years. The sample used to estimate Equation (1) consists of 52,657 observations.

After the estimation of Equation (1), we remove observations with missing information of both earnings announcement speed and management forecast accuracy and observations with missing information to calculate control variables. About one third of the observations have quantitative management guidance. Samples for regression of earning announcement speed and management forecast accuracy consist of 29,959 and 9,717 observations, respectively.

\subsection{Estimation of Labor Investment Efficiency}

We proxy labor investment efficiency with the absolute value of abnormal net hiring. Abnormal net hiring is the residual from Model (1). Panel A of Table 1 presents the descriptive statistics for variables in Model (1). The average (median) percentage change in the number of employees is 5.87\% (2.04\%), Our descriptive statistics are similar to those reported by prior studies, such as Pinnuck and Lillis (2007) and Jung et al. (2014).

Panel B of Table 1 presents the regression results for Equation (1). The coefficient of SALES_GROWTH of current year suggests that $10 \%$ increase in the sales growth is associated with $1.98 \%$ increase in the number of employees. Net hiring activities are positively related to sales growth (SALES_GROWTH) of present and previous one period, improvement of profitability (DELTA_ROA) of present and previous one period, stock return (RETURN), size relative to industry peers (SIZE_R), liquidity (QUICK), and improvement of liquidity (DELTA_QUICK) in the previous period. Significant coefficients for most predictors and the R-square of $16.22 \%$ combined suggest that Equation (1) provides reasonable estimate for net hiring.

Table 1. Estimation of the optimal level of net hiring

Panel A: Descriptive statistics (N=52,657)

\begin{tabular}{lccccc}
\hline & & & & & \\
VARIABLES & Mean & $\mathrm{SD}$ & $\mathrm{p} 25$ & Median & $\mathrm{p} 75$ \\
\hline & & & & & \\
NET_HIRE & 0.0587 & 0.2819 & -0.0476 & 0.0204 & 0.1143 \\
SALES_GROWTH & 0.1259 & 0.4944 & -0.0465 & 0.0623 & 0.1910 \\
SALES_GROWTH ${ }_{\mathrm{t}-1}$ & 0.1764 & 0.6477 & -0.0388 & 0.0696 & 0.2097 \\
ROA & -0.1096 & 0.5810 & -0.0713 & 0.0295 & 0.0809 \\
DELTA_ROA & -0.0042 & 0.3846 & -0.0456 & -0.0003 & 0.0374 \\
DELTA_ROA & 0.0146 & 0.4665 & -0.0437 & 0.0005 & 0.0401 \\
RETURN $_{\mathrm{t}-1}$ & 0.1987 & 1.0899 & -0.2775 & 0.0110 & 0.3238 \\
QUICK $_{\mathrm{t}-1}$ & 2.0056 & 2.3358 & 0.7644 & 1.2618 & 2.2598 \\
DELTA_QUICK & 0.1350 & 0.8524 & -0.2132 & -0.0129 & 0.2073 \\
DELTA_QUICK $_{\mathrm{t}-1}$ & 0.1675 & 0.9529 & -0.2061 & -0.0050 & 0.2237 \\
LEV $_{\mathrm{t}-1}$ & 0.2603 & 0.3802 & 0.0134 & 0.1785 & 0.3498 \\
LOSSBINX $_{\mathrm{t}-1}$ & 0.0137 & 0.1164 & 0.0000 & 0.0000 & 0.0000 \\
LOSSBINX $_{\mathrm{t}-1}$ & 0.0116 & 0.1072 & 0.0000 & 0.0000 & 0.0000 \\
LOSSBINX3 $_{\mathrm{t}-1}$ & 0.0121 & 0.1095 & 0.0000 & 0.0000 & 0.0000 \\
LOSSBINX4 $_{\mathrm{t}-1} 1$ & 0.0104 & 0.1014 & 0.0000 & 0.0000 & 0.0000 \\
LOSSBINX5 $_{\mathrm{t}-1}$ & 0.0095 & 0.0970 & 0.0000 & 0.0000 & 0.0000 \\
SIZE_R $_{\mathrm{t}-1}$ & 49.6804 & 29.0635 & 24.0000 & 50.0000 & 75.0000 \\
& & & & &
\end{tabular}


Panel B: Estimation results

\begin{tabular}{|c|c|}
\hline VARIABLES & NET_HIRE \\
\hline SALES_GROWTH & $\begin{array}{c}0.1975 * * * \\
(84.0193)\end{array}$ \\
\hline SALES_GROWTH $\mathrm{t}_{\mathrm{t}-1}$ & $\begin{array}{c}0.0352 * * * \\
(19.3786)\end{array}$ \\
\hline DELTA_ROA & $\begin{array}{c}-0.0561 * * * \\
(-16.3707)\end{array}$ \\
\hline DELTA_ROA $_{\mathrm{t}-1}$ & $\begin{array}{c}-0.0092 * * * \\
(-3.5559)\end{array}$ \\
\hline ROA & $\begin{array}{c}0.0009 \\
(0.3492)\end{array}$ \\
\hline RETURN & $\begin{array}{c}0.0182 * * * \\
(17.1084)\end{array}$ \\
\hline SIZE_R $\mathrm{R}_{\mathrm{t}-1}$ & $\begin{array}{c}0.0008 * * * \\
(18.2611)\end{array}$ \\
\hline QUICK $_{\mathrm{t}-1}$ & $\begin{array}{c}0.0074 * * * \\
(13.2863)\end{array}$ \\
\hline DELTA_QUICK $_{\mathrm{t}-1}$ & $\begin{array}{c}0.0181 * * * \\
(14.4560)\end{array}$ \\
\hline DELTA_QUICK & $\begin{array}{c}-0.0073 * * * \\
(-5.2568)\end{array}$ \\
\hline $\mathrm{LEV}_{\mathrm{t}-1}$ & $\begin{array}{c}-0.0192 * * * \\
(-5.4052)\end{array}$ \\
\hline LOSSBINX1 $1_{\mathrm{t}-1}$ & $\begin{array}{c}-0.0095 \\
(-0.9838)\end{array}$ \\
\hline LOSSBINX2 $2_{\mathrm{t}-1}$ & $\begin{array}{c}-0.0072 \\
(-0.6835)\end{array}$ \\
\hline LOSSBINX3 ${ }_{\mathrm{t}-1}$ & $\begin{array}{c}-0.0137 \\
(-1.3329)\end{array}$ \\
\hline LOSSBINX4 t-1 $_{\text {- }}$ & $\begin{array}{c}-0.0008 \\
(-0.0734)\end{array}$ \\
\hline LOSSBINX5 ${ }_{\mathrm{t}-1}$ & $\begin{array}{l}-0.0127 \\
(-1.0865)\end{array}$ \\
\hline CONSTANT & $\begin{array}{c}-0.0623 * * * \\
(-3.5716)\end{array}$ \\
\hline Industry FE & Yes \\
\hline Observations & 52,654 \\
\hline R-squared & 0.1622 \\
\hline
\end{tabular}

$* * *, * *, *$ denote significance at $1 \%, 5 \%$, and $10 \%$ levels (two-tail tests).

The t-statistics are reported in parentheses

Standard errors are clustered at firm level. 


\subsection{Descriptive Statistics}

Table 2 presents the descriptive statistics for variables in Equation (2). ABS_AB_NET_HIRING has a mean of 0.1174 and a median of 0.0673 . This indicates that firms' net hiring activities on average deviate $11.74 \%$ from the optimal level while the median deviation from the optimal hiring is only $6.73 \%$. There appears to be a large variation in the level of abnormal hiring. The average and median earnings announcement speed are 49.4 days and 47 days, respectively. The difference between management forecast and actual EPS on average accounts for $1 \%$ of the stock price, so management forecasts are relatively accurate.

Table 2. Descriptive statistics

\begin{tabular}{|c|c|c|c|c|c|c|}
\hline VARIABLES & $\mathrm{N}$ & Mean & SD & p25 & Median & p75 \\
\hline ABS_AB_NET_HIRE & 29959 & 0.1174 & 0.1608 & 0.0310 & 0.0673 & 0.1353 \\
\hline EA_SPEED ${ }_{\mathrm{t}-1}$ & 29959 & -0.1354 & 0.0510 & -0.1616 & -0.1288 & -0.0959 \\
\hline FORECAST_ACCURACY ${ }_{\mathrm{t}-1}$ & 9717 & -0.0100 & 0.0374 & -0.0042 & -0.0014 & -0.0005 \\
\hline $\operatorname{MTB}_{t-1}$ & 29959 & 3.1565 & 5.8870 & 1.3563 & 2.2432 & 3.7988 \\
\hline SIZE $_{t-1}$ & 29959 & 59.7154 & 24.0269 & 41.0000 & 61.0000 & 80.0000 \\
\hline QUICK $_{\mathrm{t}-1}$ & 29959 & 2.0220 & 2.1503 & 0.8530 & 1.3364 & 2.3173 \\
\hline $\mathrm{LEV}_{\mathrm{t}-1}$ & 29959 & 0.2173 & 0.2412 & 0.0127 & 0.1751 & 0.3288 \\
\hline DIVDUM $_{\mathrm{t}-1}$ & 29959 & 0.3999 & 0.4899 & 0.0000 & 0.0000 & 1.0000 \\
\hline $\mathrm{STD}_{-} \mathrm{CFO}_{\mathrm{t}-1}$ & 29959 & 158.3562 & 396.7350 & 10.6990 & 30.7435 & 101.7794 \\
\hline STD_SALE $_{\mathrm{t}-1}$ & 29959 & 634.7933 & $1,633.2732$ & 31.0307 & 108.2152 & 404.8743 \\
\hline TANGIBLE $_{\mathrm{t}-1}$ & 29959 & 0.2496 & 0.2266 & 0.0743 & 0.1698 & 0.3610 \\
\hline $\operatorname{LOSS}_{\mathrm{t}-1}$ & 29959 & 0.2751 & 0.4466 & 0.0000 & 0.0000 & 1.0000 \\
\hline STD_NET_HIRE $_{\mathrm{t}-1}$ & 29959 & 0.2183 & 0.4350 & 0.0651 & 0.1188 & 0.2225 \\
\hline LABOR_INTENSITY $_{\mathrm{t}-1}$ & 29959 & 0.0055 & 0.0078 & 0.0016 & 0.0031 & 0.0060 \\
\hline ABS_AB_INVEST_OTHER & 29959 & 0.0953 & 0.1191 & 0.0319 & 0.0631 & 0.1152 \\
\hline
\end{tabular}

\section{Empirical Results and Additional Analyses}

\subsection{Main Analyses}

Table 3 reports the estimation of Equation (2) using two proxies for internal information environment. The regression result reported in Column (1) of Table 3 examines the relation between earnings announcement speed and labor investment efficiency. The negative coefficient of EA_SPEED indicates that as firms provide more timely earnings announcement, the magnitude of abnormal investment in labor is lower. One standard deviation change in earnings announcement speed leads to $0.88 \%$-point change in the magnitude of abnormal net hiring, which has a mean value of $11.74 \%$. The results support our hypothesis and suggest that faster information integration within the organization leads to more efficient labor investment.

The regression result reported in Column (2) of Table 3 examines the relation between management forecast accuracy and labor investment efficiency. The negative coefficient of FORECAST_ACCURACY suggests that firms with higher management forecast accuracy make better decisions in the labor investment. As the forecast accuracy improves by one standard deviation, the deviation from the optimal level of labor investment decreases by $0.47 \%$. 
Table 3. Internal information environment and labor investment efficiency: Full sample

\begin{tabular}{|c|c|c|}
\hline VARIABLES & Full Sample & Full Sample \\
\hline EA_SPEED $\mathrm{t}-1$ & $\begin{array}{c}-0.1722 * * * \\
(-6.8587)\end{array}$ & \\
\hline FORECAST_ACCURACY $_{\mathrm{t}-1}$ & & $\begin{array}{c}-0.1266 * * * \\
(-3.3328)\end{array}$ \\
\hline MTB $_{\mathrm{t}-1}$ & $\begin{array}{c}0.0004 * * \\
(2.1827)\end{array}$ & $\begin{array}{c}0.0001 \\
(0.6389)\end{array}$ \\
\hline $\mathrm{SIZE}_{\mathrm{t}-1}$ & $\begin{array}{c}-0.0002 * * \\
(-2.3398)\end{array}$ & $\begin{array}{c}-0.0004 * * * \\
(-4.3968)\end{array}$ \\
\hline QUICK $_{\mathrm{t}-1}$ & $\begin{array}{c}0.0087 * * * \\
(10.5291)\end{array}$ & $\begin{array}{c}0.0060 * * * \\
(4.0855)\end{array}$ \\
\hline $\mathrm{LEV}_{\mathrm{t}-1}$ & $\begin{array}{l}0.0110 * \\
(1.7272)\end{array}$ & $\begin{array}{c}0.0135 \\
(1.3959)\end{array}$ \\
\hline DIVDUM $_{\mathrm{t}-1}$ & $\begin{array}{c}-0.0080 * * * \\
(-3.6470)\end{array}$ & $\begin{array}{c}-0.0096 * * * \\
(-2.9116)\end{array}$ \\
\hline $\mathrm{STD}_{-} \mathrm{CFO}_{\mathrm{t}-1}$ & $\begin{array}{c}-0.0000 \\
(-1.5067)\end{array}$ & $\begin{array}{c}-0.0000 \\
(-0.3781)\end{array}$ \\
\hline STD_SALE ${ }_{\mathrm{t}-1}$ & $\begin{array}{c}0.0000 \\
(1.6366)\end{array}$ & $\begin{array}{l}0.0000 * * \\
(2.3444)\end{array}$ \\
\hline TANGIBLE $_{\mathrm{t}-1}$ & $\begin{array}{c}-0.0191 * * * \\
(-2.7967)\end{array}$ & $\begin{array}{c}-0.0327 * * * \\
(-2.7614)\end{array}$ \\
\hline $\operatorname{LOSS}_{\mathrm{t}-1}$ & $\begin{array}{c}0.0205 * * * \\
(7.6765)\end{array}$ & $\begin{array}{c}0.0047 \\
(1.0070)\end{array}$ \\
\hline STD_NET_HIRE ${ }_{\mathrm{t}-1}$ & $\begin{array}{c}0.0298 * * * \\
(7.3778)\end{array}$ & $\begin{array}{c}0.0176 * * * \\
(3.1213)\end{array}$ \\
\hline LABOR_INTENSITY $_{\mathrm{t}-1}$ & $\begin{array}{c}-1.1844 * * * \\
(-8.2650)\end{array}$ & $\begin{array}{c}-0.8488 * * * \\
(-3.8660)\end{array}$ \\
\hline ABS_AB_INVEST_OTHER ${ }_{\mathrm{t}-1}$ & $\begin{array}{c}0.4315 * * * \\
(23.6295)\end{array}$ & $\begin{array}{c}0.4716^{* * *} \\
(16.5344)\end{array}$ \\
\hline CONSTANT & $\begin{array}{c}0.0711 * * * \\
(4.1526)\end{array}$ & $\begin{array}{c}0.1001 * * * \\
(6.9169)\end{array}$ \\
\hline Industry FE & Yes & Yes \\
\hline Year FE & Yes & Yes \\
\hline Observations & 29,959 & 9,717 \\
\hline R-squared & 0.1695 & 0.1821 \\
\hline
\end{tabular}


Although our study focuses on the quality of internal information used by managers, we cannot rule out the potential impact of managers self-serving incentives in their decision making. Managers' empire building incentives may cause managers to overinvest while pressure from cash shortage or meeting earnings target may cause managers to underinvest. Since labor surplus and labor shortage are due to different managerial incentives, we partition the sample into over- and under-investment group and re-estimate Equation (2). To construct the sub-sample, we define firms with overinvestment in labor, which is caused by either over-hiring or under-firing, are those with NET_HIRE above the optimal level (i.e., positive residual from the estimation of Equation (1)). We define firms with underinvestment in labor, which is caused by either over-firing or under-hiring, are those with NET_HIRE below the optimal level (i.e., negative residual from the estimation of Equation (1)).

Table 4 presents the result for this subsample analysis. The negative and significant coefficients of EA_SPEED from Column (1) and (2) suggest that when the internal information environment allows managers to quickly incorporate information from different sectors of the organization, both over- and under-investment problems are alleviated. The coefficient of FORECAST_ACCURACY is only significant for the underinvestment group (Column (3)). One potential explanation is that managers are more cautious with downsizing labor forces, which may deteriorate the firms' reputation. In this case, managers rely more on the accuracy of internal information when make decisions on excessive firing and inadequate hiring.

Table 4. Internal information environment and labor investment efficiency: Over- and Under-Investment

\begin{tabular}{|c|c|c|c|c|}
\hline VARIABLES & Overinvestment & Underinvestment & Overinvestment & Underinvestment \\
\hline EA_SPEED ${ }_{t-1}$ & $\begin{array}{c}-0.2648 * * * \\
(-5.3887)\end{array}$ & $\begin{array}{c}-0.1471 * * * \\
(-6.5526)\end{array}$ & & \\
\hline FORECAST_ACCURACY $_{\mathrm{t}-1}$ & & & $\begin{array}{c}-0.0741 \\
(-0.7818)\end{array}$ & $\begin{array}{c}-0.1628 * * * \\
(-3.6989)\end{array}$ \\
\hline MTB $_{t-1}$ & $\begin{array}{c}0.0009 * * * \\
(2.6208)\end{array}$ & $\begin{array}{c}-0.0003 \\
(-1.2794)\end{array}$ & $\begin{array}{c}0.0006 \\
(1.3086)\end{array}$ & $\begin{array}{c}-0.0005 * * \\
(-2.0763)\end{array}$ \\
\hline SIZE $_{t-1}$ & $\begin{array}{c}-0.0001 \\
(-0.9475)\end{array}$ & $\begin{array}{c}-0.0002 * * * \\
(-3.5536)\end{array}$ & $\begin{array}{c}-0.0007 * * * \\
(-3.5978)\end{array}$ & $\begin{array}{c}-0.0002 * * * \\
(-2.9253)\end{array}$ \\
\hline QUICK $_{\mathrm{t}-1}$ & $\begin{array}{c}0.0123 * * * \\
(8.6469)\end{array}$ & $\begin{array}{c}0.0063 * * * \\
(7.6206)\end{array}$ & $\begin{array}{c}0.0075 * * * \\
(2.5889)\end{array}$ & $\begin{array}{c}0.0035 * * * \\
(2.8253)\end{array}$ \\
\hline $\mathrm{LEV}_{\mathrm{t}-1}$ & $\begin{array}{c}0.0148 \\
(1.4074)\end{array}$ & $\begin{array}{c}0.0213 * * * \\
(3.3783)\end{array}$ & $\begin{array}{l}0.0362 * \\
(1.8350)\end{array}$ & $\begin{array}{c}0.0212 * * * \\
(2.5911)\end{array}$ \\
\hline $\operatorname{DIVDUM}_{\mathrm{t}-1}$ & $\begin{array}{c}-0.0101 * * \\
(-2.3134)\end{array}$ & $\begin{array}{c}0.0004 \\
(0.2147)\end{array}$ & $\begin{array}{l}-0.0169 * * \\
(-2.4370)\end{array}$ & $\begin{array}{c}0.0015 \\
(0.5875)\end{array}$ \\
\hline $\mathrm{STD}_{-} \mathrm{CFO} \mathrm{t}_{\mathrm{t}-1}$ & $\begin{array}{c}-0.0000 \\
(-1.5104)\end{array}$ & $\begin{array}{c}-0.0000 \\
(-1.1088)\end{array}$ & $\begin{array}{c}-0.0000 \\
(-1.5634)\end{array}$ & $\begin{array}{c}0.0000 \\
(1.0276)\end{array}$ \\
\hline STD_SALE $_{\mathrm{t}-1}$ & $\begin{array}{c}0.0000 \\
(1.3818)\end{array}$ & $\begin{array}{c}0.0000 * * \\
(2.3491)\end{array}$ & $\begin{array}{c}0.0000 * * \\
(2.4845)\end{array}$ & $\begin{array}{c}0.0000 \\
(1.6258)\end{array}$ \\
\hline TANGIBLE $_{\mathrm{t}-1}$ & $\begin{array}{c}-0.0449 * * * \\
(-3.4063)\end{array}$ & $\begin{array}{c}-0.0057 \\
(-0.9004)\end{array}$ & $\begin{array}{c}-0.0961 * * * \\
(-3.6568)\end{array}$ & $\begin{array}{c}-0.0140 \\
(-1.5023)\end{array}$ \\
\hline $\operatorname{LOSS}_{\mathrm{t}-1}$ & $\begin{array}{c}-0.0014 \\
(-0.2662)\end{array}$ & $\begin{array}{c}0.0387 * * * \\
(16.2082)\end{array}$ & $\begin{array}{c}-0.0197 * * \\
(-2.0000)\end{array}$ & $\begin{array}{c}0.0224 * * * \\
(5.5386)\end{array}$ \\
\hline STD_NET_HIRE $_{\mathrm{t}-1}$ & $\begin{array}{c}0.0367 * * * \\
(4.9597)\end{array}$ & $\begin{array}{c}0.0226 * * * \\
(6.8508)\end{array}$ & $\begin{array}{l}0.0203 * \\
(1.6731)\end{array}$ & $\begin{array}{c}0.0185 * * * \\
(3.6343)\end{array}$ \\
\hline
\end{tabular}




$\begin{array}{lcccc}\text { LABOR_INTENSITY }_{\mathrm{t}-1} & -2.6059 * * * & -0.1399 & -1.7354 * * & 0.0040 \\ & (-8.8667) & (-1.0367) & (-4.5080) & (0.0174) \\ \text { ABS_AB_INVEST_OTHER } \mathrm{t}-1 & 0.4928 * * * & 0.1504 * * * & 0.5117 * * * & 0.0730 * * * \\ & (23.4686) & (6.8348) & (15.6807) & (2.8319) \\ \text { CONSTANT } & 0.0970 * * * & 0.0475 * * * & 0.1417 * * * & 0.0823 * * * \\ & (3.3505) & (3.6530) & (4.5901) & (4.6995) \\ \text { Industry FE } & \text { Yes } & \text { Yes } & \text { Yes } & \text { Yes } \\ \text { Year FE } & \text { Yes } & \text { Yes } & \text { Yes } & \text { Yes } \\ \text { Observations } & 11,993 & 17,966 & 3,791 & 5,926 \\ \text { R-squared } & 0.1908 & 0.1647 & 0.2319 & 0.0913\end{array}$

$* * *, * *, *$ denote significance at $1 \%, 5 \%$, and $10 \%$ levels (two-tail tests).

The t-statistics are reported in parentheses

Standard errors are clustered at firm level.

\subsection{The Role of Labor Union}

\subsubsection{The Impact of Labor Union on Labor Investment Decisions}

Employees are claimants for firms' profit and labor unions' goal is to seek better wages, welfare, and job security for employees rather than to maximize firm value. Thus, labor unions have incentives to extract rents from firms. If firms do not reach agreement with labor unions, labor unions may initiate strikes, lawsuits, and protests, which will damage firms' economic profits and reputation. To avoid costs derived from firms' conflicts with labor union, firms deviate from the optimal business plans.

Labor unions have impact on investment decisions. Grout (1984) theorizes that firms reduce investments in the absence of binding contracts with labor union and Fallick and Hassett (1999) document declines in investment following the union certification. Due to labor unions' rent-seeking behavior, unionized firms are more likely to have lower profits (Hirsch, 1991), lower level R\&D investment (Connolly, Hirsch, \& Hirschey, 1986; Hirsch \& Link, 1987), lower employee growth (Bronars \& Deere, 1993), and less risky investment (Farber, Hsieh, Jung, \& Yi, 2010). Although labor unions' rent seeking activities may deteriorate firm value, labor unions also perform monitoring to constrain managers' opportunistic behavior. Shin, Tinaikar, and Zhang (2016) recently document that firms from unionized industries are less likely to over- and under-invest in physical assets and R\&D.

Unlike other investments, labor investments are directly associated with the quasi-rents of labor unions. In order to protect current employees' interest, labor unions are more likely to prevent firms from hiring and firing. Even if managers identify inefficient workers, realize that the firm has reached the production capacity, or have a clear prospect for the firm's future performance, they may not be able to adjust the labor investment due to pressure from labor unions. If a company has high quality internal information, there will be lower information asymmetry within the organization. The labor union is more likely to be aware of the difficulties faced by the company and the managers can develop stronger argument against the labor union with more timely and accurate internal information. In this case, it will be easier for managers to reach an agreement with the labor union. The positive association between internal information quality and labor investment efficiency should not be limited to industries with lower union coverage.

\subsubsection{Measure of Labor Union Coverage and Cross-sectional Analysis}

We use industry level labor union coverage percentage disclosed by Union Membership and Coverage Database. This database uses Bureau of Census Industry Codes (CIC) as industry identifier. In order to link the CIC to SIC, we first identify unique NAICS-SIC pairs in each year from COMPUSTAT. We then follow the links between CIC and NAICS based on the information from US Census Bureau and manually find the corresponding SIC for each CIC. The US Census Bureau revised CIC in 2002, 2007, 2012, and 2017 and new CIC become effective from the year following revision. We assume the links/matching between CIC and NAICS remain unchanged for the periods 2003-2007, 2008-2012, and 2013-2017. We rank labor union coverage into quartile by year and define a firm is in an industry of high unionization if the industry level union coverage is in the top quartile in the previous year. We next partition the sample into high union coverage and low union coverage groups. 
After partitioning our sample, we re-estimate Equation (2) for both the high unionization and low unionization group. Table 5 presents the cross-sectional regression results. Both EA_SPEED and FORECAST_ACCURACY are negatively associated with the magnitude of abnormal hiring activities. Firms in both high and low union coverage industries benefit from higher internal information quality. We further compare the coefficients of two internal information quality proxies between the high and low unionization group. We observe that the magnitude of the coefficients in the high unionization group is significantly larger.

Table 5: Internal information environment and labor investment efficiency: High- and Low-Unionization

\begin{tabular}{|c|c|c|c|c|}
\hline VARIABLES & $\begin{array}{l}\text { High Union } \\
\text { Coverage }\end{array}$ & $\begin{array}{c}\text { Low Union } \\
\text { Coverage }\end{array}$ & $\begin{array}{l}\text { High Union } \\
\text { Coverage }\end{array}$ & $\begin{array}{c}\text { Low Union } \\
\text { Coverage }\end{array}$ \\
\hline EA_SPEED ${ }_{\mathrm{t}-1}$ & $\begin{array}{c}-0.1770 * * * \\
(-4.1699)\end{array}$ & $\begin{array}{c}-0.1718 * * * \\
(-5.5926)\end{array}$ & & \\
\hline FORECAST_ACCURACY $_{\mathrm{t}-1}$ & & & $\begin{array}{l}-0.1579^{\dagger} \\
(-1.4401)\end{array}$ & $\begin{array}{c}-0.1164 * * * \\
(-2.7955)\end{array}$ \\
\hline MTB $_{t-1}$ & $\begin{array}{c}0.0004 \\
(1.1778)\end{array}$ & $\begin{array}{c}0.0004 \\
(1.6451)\end{array}$ & $\begin{array}{c}-0.0001 \\
(-0.5177)\end{array}$ & $\begin{array}{c}0.0002 \\
(0.5441)\end{array}$ \\
\hline $\operatorname{SIZE}_{t-1}$ & $\begin{array}{c}-0.0003 * * \\
(-2.5339)\end{array}$ & $\begin{array}{l}-0.0001 * \\
(-1.7429)\end{array}$ & $\begin{array}{c}-0.0008^{* * *} \\
(-3.1703)\end{array}$ & $\begin{array}{c}-0.0004 * * * \\
(-3.6641)\end{array}$ \\
\hline QUICK $_{\mathrm{t}-1}$ & $\begin{array}{c}0.0076 * * * \\
(3.7979)\end{array}$ & $\begin{array}{c}0.0085^{* * * *} \\
(9.4507)\end{array}$ & $\begin{array}{c}0.0017 \\
(0.3853)\end{array}$ & $\begin{array}{c}0.0062 * * * \\
(4.0064)\end{array}$ \\
\hline $\mathrm{LEV}_{\mathrm{t}-1}$ & $\begin{array}{c}0.0129 \\
(1.3410)\end{array}$ & $\begin{array}{c}0.0113 \\
(1.4515)\end{array}$ & $\begin{array}{c}0.0093 \\
(0.5106)\end{array}$ & $\begin{array}{c}0.0165 \\
(1.4305)\end{array}$ \\
\hline $\operatorname{DIVDUM}_{\mathrm{t}-1}$ & $\begin{array}{c}-0.0003 \\
(-0.0808)\end{array}$ & $\begin{array}{c}-0.0100 * * * \\
(-3.9986)\end{array}$ & $\begin{array}{c}-0.0065 \\
(-0.8635)\end{array}$ & $\begin{array}{c}-0.0085^{* *} \\
(-2.3798)\end{array}$ \\
\hline $\mathrm{STD}_{-} \mathrm{CFO} \mathrm{t}_{\mathrm{t}-1}$ & $\begin{array}{c}-0.0000 \\
(-0.0117)\end{array}$ & $\begin{array}{l}-0.0000 * \\
(-1.6888)\end{array}$ & $\begin{array}{c}0.0000 \\
(0.6969)\end{array}$ & $\begin{array}{c}-0.0000 \\
(-0.8345)\end{array}$ \\
\hline $\mathrm{STD}_{-} \mathrm{SALE} \mathrm{t}_{\mathrm{t}-1}$ & $\begin{array}{c}0.0000 \\
(0.6538)\end{array}$ & $\begin{array}{c}0.0000 * * \\
(2.4122)\end{array}$ & $\begin{array}{c}0.0000 \\
(1.4213)\end{array}$ & $\begin{array}{c}0.0000 * * \\
(2.0118)\end{array}$ \\
\hline TANGIBLE $_{\mathrm{t}-1}$ & $\begin{array}{c}-0.0137 \\
(-1.2682)\end{array}$ & $\begin{array}{c}-0.0298 * * * \\
(-3.3985)\end{array}$ & $\begin{array}{c}-0.0056 \\
(-0.2757)\end{array}$ & $\begin{array}{c}-0.0575 * * * \\
(-4.1162)\end{array}$ \\
\hline $\operatorname{LOSS}_{\mathrm{t}-1}$ & $\begin{array}{c}0.0124 * * \\
(2.3500)\end{array}$ & $\begin{array}{c}0.0220 * * * \\
(7.1910)\end{array}$ & $\begin{array}{c}-0.0151 \\
(-1.4702)\end{array}$ & $\begin{array}{l}0.0086^{*} \\
(1.6832)\end{array}$ \\
\hline STD_NET_HIRE $\mathrm{t}_{\mathrm{t}-1}$ & $\begin{array}{c}0.0130 * * * \\
(2.8493)\end{array}$ & $\begin{array}{c}0.0384 * * * \\
(7.1770)\end{array}$ & $\begin{array}{c}0.0082 \\
(0.8977)\end{array}$ & $\begin{array}{c}0.0215^{* * *} * \\
(3.3295)\end{array}$ \\
\hline LABOR_INTENSITY $_{\mathrm{t}-1}$ & $\begin{array}{c}-2.4244 * * * \\
(-3.7268)\end{array}$ & $\begin{array}{c}-1.0139 * * * \\
(-7.0635)\end{array}$ & $\begin{array}{c}-3.3738 * * * \\
(-3.0785)\end{array}$ & $\begin{array}{c}-0.6000 * * * \\
(-2.7759)\end{array}$ \\
\hline ABS_AB_INVEST_OTHER ${ }_{\mathrm{t}-1}$ & $\begin{array}{c}0.5880 * * * \\
(16.1089)\end{array}$ & $\begin{array}{c}0.3904 * * * \\
(18.9118)\end{array}$ & $\begin{array}{c}0.5621 * * * \\
(10.0475)\end{array}$ & $\begin{array}{c}0.4453 * * * \\
(13.6276)\end{array}$ \\
\hline CONSTANT & $\begin{array}{l}0.0661 * \\
(1.7686)\end{array}$ & $\begin{array}{c}0.0748 * * * \\
(3.9570)\end{array}$ & $\begin{array}{c}0.2789 * * * \\
(6.4804)\end{array}$ & $\begin{array}{c}0.0962 * * * \\
(6.2276)\end{array}$ \\
\hline Industry FE & Yes & Yes & Yes & Yes \\
\hline
\end{tabular}




$\begin{array}{lcccc}\text { Year FE } & \text { Yes } & \text { Yes } & \text { Yes } & \text { Yes } \\ \text { Observations } & 8,550 & 21,409 & 2,347 & 7,370 \\ \text { R-squared } & 0.1847 & 0.1716 & 0.2150 & 0.1840\end{array}$

$* * *, * *, *$ denote significance at 1\%, 5\%, and 10\% levels (two-tail tests).

$\dagger$ denote significance at $10 \%$ level(one-tail tests)

The t-statistics are reported in parentheses

Standard errors are clustered at firm level.

\subsection{Other Robustness Tests}

We also conduct some other robustness tests. First, we consider alternative measure of labor investment efficiency by including capital investment, R\&D expenditure, PPE balance, union coverage, and GDP in the estimation of normal net hiring (Equation (1)). Second, we use the industry level union coverage percentage instead of an indicator variable to capture unionization. Third, we replace lagged variables in Equation (2) with their contemporaneous forms. Results remain robust in all of the above tests. Fourth, we further explore two channels (i.e. corporate governance and product market competition) through which the internal information environment may influence the labor investment efficiency. We find that the association between internal information environment and labor investment efficiency is not conditional on the corporate governance. In contrast, this association is more pronounced for firms in highly competitive product market. (Note 4)

\section{Conclusion Remarks}

Increasing employment cost and low efficiency in US firms' labor investment call for the need to improve labor investment efficiency. We posit a positive relation between internal information quality and labor investment efficiency for three reasons. First, more transparent internal information environment helps managers to obtain better understanding of current production capacity. Second, better internal information environment assists managers to identify deficiency in production and evaluate employees' performance. Third, better internal information environment allows managers to acquire more accurate and timely information from subordinate managers, which help managers develop a clearer prospect for the firm's future performance.

We find an association between high quality internal information and efficient labor investment. This association is not limited to firms in less unionized industry and is robust to both under- and over- investment subsamples. In this paper we focus on addressing the association between internal information environment and labor investment efficiency, but not able to fully implement the causality. The endogeneity problem can be driven by various characteristics including management and firm characteristics (Coles \& Li, 2020, Li, 2016). There are three main reasons that the causality might fail. First, omitted variables. Given the literature is new and the determinants of labor investment efficiency is yet fully revealed. Hence omitted variable can be a potential drawback in this study. Possible solution is to include more firms, including the management and corporate board characteristics as well as industry characteristics to alleviate this concern. By controlling for industry-year fixed effect, we managed to control for unobservable industry time varying variables, and the results remain the same. Second concern is the reverse causality. This concern has been addressed by using one-year lag variables for regressors. Third, the labor investment efficiency and internal information quality are affected together by other factors, i.e. the endogeneity concern. Possible solution for this concern is to look for exogeneous variations in internal information quality. Given the literature of internal information quality is still new, few plausible event or instrumental variable is known to us, and it will be a very interesting topic for future research. In sum, we establish the association between internal information quality and labor investment efficiency, and this association lies at the intersection corporate management and information quality.

\section{References}

Beatty, A., Liao, S., \& Yu, J. J. (2013). The spillover effect of fraudulent financial reporting on peer firms' investments. Journal of Accounting and Economics, $\quad 55(2-3), \quad 183-205$. https://doi.org/10.1016/j.jacceco.2013.01.003

Becker, B., \& Gerhart, B. (1996). The impact of human resource management on organizational performance: Progress and prospects. Academy of Management Journal, 39(4), 779-801. https://doi.org/10.5465/256712

Ben-Nasr, H., \& Alshwer, A. A. (2016). Does stock price informativeness affect labor investment efficiency?. Journal of Corporate Finance, 38, 249-271. https://doi.org/10.1016/j.jcorpfin.2016.01.012 
Biddle, G. C., Hilary, G., \& Verdi, R. S. (2009). How does financial reporting quality relate to investment efficiency?. Journal of Accounting and Economics, 48(2-3), 112-131. https://doi.org/10.1016/j.jacceco.2009.09.001

Bronars, S. G., \& Deere, D. R. (1993). Unionization, incomplete contracting, and capital investment. Journal of Business, 66 (1), 117-132. https://doi.org/10.1086/296596

Cassar, G., \& Gibson, B. (2008). Budgets, internal reports, and manager forecast accuracy. Contemporary Accounting Research, 25(3), 707-738. https://doi.org/10.1506/car.25.3.3

Chen, C., Martin, X., Roychowdhury, S., Wang, X., \& Billett, M. T. (2018). Clarity begins at home: Internal information asymmetry and external communication quality. The Accounting Review, 93(1), 71-101. https://doi.org/10.2308/accr-51842

Cheng, Q., Cho, Y. J., \& Yang, H. (2018). Financial reporting changes and the internal information environment: Evidence from SFAS 142. Review of Accounting Studies, 23(1), 347-383. https://doi.org/10.1007/s11142-017-9437-8

Cobb, C. W., \& Douglas, P. H. (1928). A theory of production. The American Economic Review, 18(1), 139-165. https://www.jstor.org/stable/1811556

Coles, J. L., \& Li, Z. (2020). Managerial attributes, incentives, and performance. The Review of Corporate Finance Studies, 9(2), 256-301. https://doi.org/10.1093/rcfs/cfaa004

Connolly, R. A., Hirsch, B. T., \& Hirschey, M. (1986). Union rent seeking, intangible capital, and market value of the firm. The Review of Economics and Statistics, 567-577. https://doi.org/10.2307/1924515

Dechow, P. M., Ge, W., Larson, C. R., \& Sloan, R. G. (2011). Predicting material accounting misstatements. Contemporary Accounting Research, 28(1), 17-82. https://doi.org/10.1111/j.1911-3846.2010.01041.x

Ding, H., Ni, X., \& Xu, H. (2020). Short selling and labor investment efficiency: evidence from the Chinese stock market. Accounting \& Finance. In-Press. https://doi.org/10.1111/acfi.12671

Dorantes, C. A., Li, C., Peters, G. F., \& Richardson, V. J. (2013). The effect of enterprise systems implementation on the firm information environment. Contemporary Accounting Research, 30(4), 1427-1461. https://doi.org/10.1111/1911-3846.12001

Fallick, B. C., \& Hassett, K. A. (1999). Investment and union certification. Journal of Labor Economics, 17(3), 570-582. https://doi.org/10.1086/209931

Fama, E. F., \& French, K. R. (1997). Industry costs of equity. Journal of Financial Economics, 43(2), 153-193. https://doi.org/10.1016/S0304-405X(96)00896-3

Farber, D. B., Hsieh, H., Jung, B., \& Yi, H. (2010). Labor unions and accounting conservatism SSRN. https://doi.org/10.2139/SSRN.1269010

Gallemore, J., \& Labro, E. (2015). The importance of the internal information environment for tax avoidance. Journal of Accounting and Economics, 60(1), 149-167. https://doi.org/10.1016/j.jacceco.2014.09.005

Ghaly,M., Dang, V. A. \& Stathopoulos, K.(2020) Institutional Investors' Horizons and Corporate Employment Decisions. Journal of Corporate Finance, Forthcoming. http://dx.doi.org/10.2139/ssrn.2606272

Gong, G., Li, L. Y., \& Xie, H. (2009). The association between management earnings forecast errors and accruals. The Accounting Review, 84(2), 497-530. https://doi.org/10.2308/accr.2009.84.2.497

Grout, P. A. (1984). Investment and wages in the absence of binding contracts: A Nash bargaining approach. Econometrica: Journal of the Econometric Society, 449-460. http://doi.org/10.2307/1911498

Heitzman, S., \& Huang, M. (2019). Internal information quality and investment sensitivities to market value and cash flow. Contemporary Accounting Research, 36 (3), 1699-1723. https://doi.org/10.1111/1911-3846.12468

Hirsch, B. T., \& Link, A. N. (1987). Labor union effects on innovative activity. Journal of Labor Research, 8(4), 323-332. https://doi.org/10.1007/BF02685217

Hirsch, B. T. (1991). Union coverage and profitability among US firms. The Review of Economics and Statistics, 69-77. https://doi.org/10.2307/2109688 
Hoberg, G., Phillips, G., \& Prabhala, N. (2014). Product market threats, payouts, and financial flexibility. The Journal of Finance, 69(1), 293-324. https://doi.org/10.1111/jofi.12050

Huang, K., Lao, B., \& McPhee, G. (2020). Internal information quality and patent-related innovation. Journal of Business Finance \& Accounting, 47(3-4), 489-518. https://doi.org/10.1111/jbfa.12439

Jennings, J. N., Seo, H., \& Tanlu, L. (2019). The effect of organizational complexity on earnings forecasting behavior. SSRN. http://dx.doi.org/10.2139/ssrn.2130119

Jung, B., Lee, W. J., \& Weber, D. P. (2014). Financial reporting quality and labor investment efficiency. Contemporary Accounting Research, 31(4), 1047-1076. https://doi.org/10.1111/1911-3846.12053

Jung, B., Kim, B., Lee, W. J., and Yoo, C. Y. (2016). Are Layoff Decisions of American Corporations Efficient. KAIST College of Business Working Paper Series 2016-001. https://doi.org/10.2139/ssrn.2720148

Jung, B., Kang, T., Lee, W. J., \& Zhou, G. (2020). Pro-Labor Institutions and Corporate Employment Efficiency. Journal of Accounting, Auditing \& Finance, In-Press. https://doi.org/10.1177\%2F0148558X20929859

Khedmati, M., Sualihu, M. A., \& Yawson, A. (2019). CEO-director ties and labor investment efficiency. Journal of Corporate Finance, In-Press. https://doi.org/10.1016/j.jcorpfin.2019.101492

Li, F. (2011). Earnings quality based on corporate investment decisions. Journal of Accounting Research, 49(3), 721-752. https://doi.org/10.1111/j.1475-679X.2010.00397.x

Li, F. (2016). Endogeneity in CEO power: A survey and experiment. Investment Analysts Journal, 45(3), 149-162. https://doi.org/10.1080/10293523.2016.1151985

McGuire, S. T., Rane, S. G., \& Weaver, C. D. (2018). Internal information quality and tax-motivated income shifting. The Journal of the American Taxation Association, 40(2), 25-44. https://doi.org/10.2308/atax-51959

Pinnuck, M., \& Lillis, A. M. (2007). Profits versus losses: Does reporting an accounting loss act as a heuristic trigger to exercise the abandonment option and divest employees?. The Accounting Review, 82(4), 1031-1053. https://doi.org/10.2308/accr.2007.82.4.1031

Shin, Y. C., Tinaikar, S., \& Zhang, Y. (2016). The impact of labor unionization on corporate overinvestment and underinvestment. SSRN. https://dx.doi.org/10.2139/ssrn.2719787

Veltri, S., \& Silvestri, A. (2011). Direct and indirect effects of human capital on firm value: evidence from Italian companies. Journal of Human Resource Costing \& Accounting, 15(3), 232-254. https://doi.org/10.1108/14013381111178596

Xiong, F., Zheng, Y., An, Z., \& Xu, S. (2020). Does internal information quality impact corporate cash holdings? Evidence from China. Accounting \& Finance. In-Press. https://doi.org/10.1111/acfi.12657

Weber, D. P., \& Zheng, K. (2017). Internal information quality and capital allocation within conglomerates. University of Connecticut School of Business Research Paper, (17-11). https://dx.doi.org/10.2139/ssrn.3074629

Zhang, Z., Ntim, C. G., Zhang, Q., \& Elmagrhi, M. H. (2020). Does accounting comparability affect corporate employment decision-making? The British Accounting Review, In-Press. https://doi.org/10.1016/j.bar.2020.100937 


\section{Notes}

Note 1. http://www.bls.gov/news.release/eci.nr0.htm

Note 2. ABS_AB_INVEST_OTHER is the magnitude of the residual of this following equation:

INVEST_OTHER $R_{i t}=\beta_{0}+\beta_{1} S A L E S \_G R O W T H_{i t-1}+\varepsilon_{i t} \quad, \quad$ where INVEST_OTHER= (CAPX+AQC+XRD-SPPE)/ Lagged AT.

Note 3. Union Membership and Coverage Database https://www.unionstats.com/

Note 4. To explore the corporate governance channel, we include the indicator variable that captures whether the CEO is also the board chair and the interaction of this indicator variable with two proxies for internal information quality. The interaction term is not significant while the coefficients for EA_SPEED and DORECAST_ACCURACY are still significant and negative. To explore the market competition channel, we include product market fluidity (Hoberg, Phillips \& Prabhala 2014) and its interaction with two proxies for internal information quality. The coefficient of this interaction term is negative and significant in one-tail test.

\section{Copyrights}

Copyright for this article is retained by the author(s), with first publication rights granted to the journal.

This is an open-access article distributed under the terms and conditions of the Creative Commons Attribution license (http://creativecommons.org/licenses/by/4.0/). 